\title{
Exploring Linguistic, Cultural, and Religious Diversity in Canadian Schools: Pre-Service Teachers' Learning from Immigrant Parents
}

\author{
Yan Guo \\ yanguo@ucalgary.ca
}

\begin{abstract}
The knowledge immigrant parents hold about their children is often unrecognized by Canadian educational systems. Parent knowledge has vital implications for Canadian school systems and for teacher preparation. Based on interviews of parents from 15 countries, this study presented three types of parent knowledge: First language, cultural and religious knowledge. Then, parent knowledge was shared with a group of pre-service teachers. Results reveal some pre-service teachers encouraged the use of students' first language in their practicum whereas others internalized their monolingual ideology despite multilingual realities. They recognized cultural misunderstanding between immigrant parents and Canadian teachers and systemic racism, and questioned the feasibility of accommodating everyone's religious needs. The study calls for the reconstruction of difference and the inclusion of epistemological pluralism, particularly immigrant parent knowledge, within teacher education. The study also suggests that it is important to help pre-service teachers shift their representation of multilingualism from being a problem to a resource, challenge their Eurocentric perspectives, understand immigrant students' cultural backgrounds, and address religious-based exemptions and accommodation.
\end{abstract}

\section{Introduction}

Immigration is now the main source of Canada's population growth. This has significant implications for Canadian school systems, and for the preparation of teachers. According to the 2006 Census, almost 6.3 million people, that is, about one out of every five people in Canada, speak languages other than English or French as their mother tongue (Statistics Canada, 2008). Moreover, the long-term prospect for this population is continued growth (Statistics Canada, 2005). Calgary is the largest recipient of immigrants and English as a Second Language (ESL) students in Alberta, and the fourth largest such urban area in Canada, after Toronto, Vancouver, and Montreal. The number of ESL students in schools is growing rapidly. In Alberta, for example, there were 14,673 ESL students enrolled in provincial schools in 1989 - a figure that rose to 71,541 in 2011 (Alberta Education, 2011). The Calgary Board of Education enrolled about 25,000 ESL learners in 2011.

Earlier immigrants coming to Canada were mostly Europeans. Today's immigrants are mostly from Asia, Africa, the Middle East, Central and South America, and the Caribbean (Statistics Canada, 2007). Educated and technically proficient, most of these immigrants are professionals, entrepreneurs and tradespersons, resulting in increasing diversity in terms of socio-educational background, economic purpose, and, mostly importantly for the relevance to this study, languages, cultures and religions. Increasing numbers of multilingual, multicultural and multireligious learners in Canadian classrooms flow from contemporary complex migration patterns.

Journal of Contemporary Issues in Education, 2012, 7 (1), Special Issue, pp.4-23

ISSN 1916-3460 @ 2011 University of Alberta

http://ejournals.library.ualberta.ca/index.php/cpi/index 
The preparation of teachers, however, has not yet caught up to these demographic changes. Pre-service teachers still tend to be white, middle-class, female and monolingual (Hodgkinson, 2002). Most teacher preparation programs, however, neglect the needs of ESL students and most classroom teachers have not received preparation to help ESL learners achieve their best. A recent report on ESL education in Ontario states: "The state of ESL in large, multi-ethnic school boards is abysmal, and, in essence, a betrayal of the public trust. The reality is that ESL students are denied access to supports necessary for their academic success" (Meyer, 2003, p.3).

In addition to appropriate university preparation, immigrant parents represent an important yet relatively untapped source for teachers' pre-service and ongoing professional learning. Immigrant parents bring their values, language, culture, religion and educational backgrounds to our schools, enriching our educational environments. The literature on immigrant parents, however, tends to employ deficit models, highlighting parents' inability to speak English, and their difficulties in communicating with schools (Bitew \& Ferguson, 2010; Guo, 2006). In opposition to the dominant discourse of immigrant parents as the problematic "Others" in Canadian schools, this study examines how pre-service teachers can learn to incorporate immigrant parent knowledge regarding the linguistic, cultural and religious diversity in their practicum schools.

\section{Theoretical Frameworks and Prior Research}

\section{Fear of Diversity and Difference as Deficit}

Research has consistently shown that many pre-service teachers are not well prepared to work effectively with immigrant parents (Guo, 2006; Jones, 2002; Malatest \& Associates, 2003; Turner, 2007). In their daily encounters with cultural diversity, many teachers face barriers to understanding diversity. One such barrier is a generalized fear of diversity (Palmer, 1998). There are growing research evidences that show that most preservice teachers reported they had attended predominantly white, middle class schools and had limited prior experiences with diversity, leading to fear, anxiety and uncertainty about their preparedness to work effectively with diverse student population (Milner, 2003; Taylor \& Sobel, 2001). These feelings were heightened by the immediate need to design culturally relevant pedagogy for the diverse children in their field experience settings (Dunn, Kirova, Cooley \& Ogilvie, 2009). Some pre-service teachers reported that the discussion about diversity in the university classes helpful, but they did not know how to translate knowledge about diversity into pedagogical practice (Guo, Arthur \& Lund, 2009).

Some teachers develop fear of Muslims, particularly after the September $11^{\text {th }}$ attack on New York's World Trade Center (McDonough \& Hoodfar, 2005). Islam is often portrayed as an inherently violent religion and Muslims are seen as threatening the peace and security of Western nations (McDonough \& Hoodfar, 2005). This reflects a broader lack of knowledge and readiness to approach cultural and religious diversity. Fear and unfamiliarity are exacerbated by curriculum and teaching practices in K-12 education, which are characterized by Eurocentric perspectives, standards and values, and 
do not reflect the knowledge and experiences of our culturally and religiously diverse student and parent population.

A tendency to regard "difference as deficit" (Dei, 1996) erects a further barrier to teachers' learning about diversity. Rather than drawing on different cultural groups as sources of alternative strengths, experiences, knowledge, and perspectives, teachers may ignore diversity, minimize it, or perceive it as an obstacle to the learning process (Cummins, 2003; Dei, 1996). Shultz (2011) critiques education that solely focuses on North American or Eurocentric perspectives runs risks of educating about "Others" as deficient victims. Deficient thinking includes overgenerations about family background, low expectations, caring at the expense of academics, and a monocultural view of childrearing practices and success. Many educators believe that many of their ESL students' educational risks could be linked to sociocultural factors such as poverty, limited English proficiency, and racial or ethnic minority status. For example, some student teachers made comments like: "Today a lot of these kids are from immigrant homes. They have parents who don't speak English." As such, these generalizations particularly perpetuate the view that ESL children and families are deficient and in need of remediation. Deficient thinking permeates the general society, mirroring particularly in schools. School culture and climate lead to institutional practices that systematically marginalize or pathologize difference.

The equation of "difference" with "deficiency" also means that pre-service teachers and school administrators often fail to recognize and draw on knowledge that immigrant parents hold about their children (Jones, 2003; Ramirez, 2003). School staff may hold beliefs - often tacit - that the knowledge of immigrants, particularly those from developing countries, is incompatible, inferior, and hence, invalid (Abdi, 2007; Dei, 1996). Non-recognition of immigrant parents' knowledge can again be causally attributed to misconceptions about difference, and lack of knowledge about different cultures (Guo, 2009; Honneth, 1995).

\section{Immigrant Parent Knowledge}

The extent to which parent knowledge is gained and used may be modelled as "transcultural knowledge construction," whereby individuals in immigrant societies of the new world change themselves by merging ways of life brought from their home countries with customs and knowledge gained from cultures they encounter in their new country. This dynamic learning process can lead to opposition and discrimination, or to cultural creativity and the integration of new knowledge within academic and societal positionings (Hoerder, Hébert \& Schmitt, 2006).

Knowledge is power; knowledge is socially constructed, culturally mediated, and historically situated (McLaren, 2003). The nature of knowledge as social relations raise important questions: "What counts as legitimate knowledge? How and why does knowledge get constructed the way it does? Whose knowledge is considered valuable? Whose knowledge is silenced? Is knowledge racialized?" (Guo, 2009, p. 47). When a teacher is presented with different forms of knowledge, her decision of how to use that knowledge will be based on what she judges to be legitimate knowledge. Research 
evidences show that educators often perceive immigrant parents, particularly those from developing countries, do not have expertise in education and their knowledge can be discounted easily (Guo, in press).

At the heart of the nature of knowledge as social relations is a notion of culture as a dynamic entity, as a way of using social, cultural, physical, spiritual, economic, and symbolic resources to make one's way in the world. Mobilizing such knowledge systematically in the classroom by teachers and administrators would promote insightful connections between curricular goals and immigrant students' experiences in countries of origin, in transition, and in residence in the local community, in turn making sense of transcultural flows and attachments to locality (Appadurai, 1996; Hannerz, 1992).

In addition to socially mediated forms of knowledge, immigrant parents' personal knowledge can play an important role in school relations. Personal knowledge here refers to wisdom that comes with embodied meaning (Polanyi, 1958). In 1958, Polanyi wrote, "Into every act of knowing there enters a passionate contribution of the person knowing what is being known, and this coefficient is no mere imperfection but a vital component of his knowledge" (1958, p. viii), stressing that "It is not words that have meaning, but the speaker or listener who means something by them" (p. 252). Personal thought depends on the central agency of human intelligence, to "sustain the student's effort to understand what he is being taught," guided by common standards and consensus (1958, p. 257). For him, "the informal act of assertion and the equally informal act of discovery" are logically related; both are "essentially unformalizable, intuitive mental decisions" (p. 261). Drawing upon subjective knowledge in the form of thoughts, observations, experiences and perspectives to further understand participant perspectives, a person's initial sketchy ideas become metaphors and categories when reflected upon, to eventually become patterned and thematic conclusions and interpretations (Creswell, 1997; Miles \& Huberman, 1984). Thus, with the confident use of language, individuals participate personally in the powerful process of construction of their own knowledge. Parent personal knowledge is knowledge gained from lived experience in all aspects of life-at work, at play, with family and friends, and so on. It has temporal dimensions in that it resides in "the person's past experience, in the person's present mind and body, and in the person's future plans and actions" (Connelly \& Clandinin, 1988, p. 25). Parent knowledge includes that drawn from their own educational backgrounds, their professional and personal experiences of interacting with schools in their countries of origin as well as their current understanding of the host country's education system, their own struggles as immigrant parents, and their future aspirations for their children (Guo, in press; Pushor, 2008).

Portuguese sociologist Boaventura de Souza Santos (2007) uses the metaphor of "the abyssal line" to critique epistemological dominance in Eurocentric cultures. This means on this side of the line, Europe and America have knowledge; as seen from this side of the line, on the other side such as in Asia and Africa, there is no real knowledge. As mentioned above, today's immigrants are mostly from Asia, Africa, the Middle East, Central and South America, and the Caribbean (Statistics Canada, 2007). Eurocentric knowledge is perceived as global and universal whereas immigrant parent knowledge as 
deficient and lacking. Currently, immigrant parent knowledge and engagement go unrecognized, possibly unwanted because it does not correspond to the norm of white, middle-class parents (Guo, 2006, 2011; Lareau, 2003). Immigrant parents often feel excluded from decision making that could improve their children's learning (Bernhard, Freire, Pacini-Ketchabaw \& Villanueva, 1998).

\section{Reflection as Practitioner Knowledge}

Reflection on practice, considered a staple of quality teacher learning, has gained currency in ESL research and practice. John Dewey (1933) defined "reflection" as the "active, persistent and careful consideration of any belief or supposed form of knowledge in light of the grounds that support it" (p. 9).

Dewey also acknowledged the importance of translating beliefs into action. Similarly, Schön (1983) described action as an essential aspect of the reflective process. In his view, reflective practitioners are those who engage in reflection-in-action by observing and critiquing their own thought processes and actions. The original concept of reflection-in-action may be complemented by reflection-on-action - that is teachers' reflections on their teaching theories and procedures both before and after teaching (Calderhead \& Gates, 1993; Cosh, 1998; Guo, 2005).

In the study that follows, I asked pre-service teachers to reflect upon their interpretations of ESL parents' knowledge and teaching in addressing the needs of ESL students. This third notion of reflection, as subjective and personal knowledge, will be also examined as a possible bridge toward awareness of the biases and prejudices preservice teachers may have about ESL students, transcultural understanding, acceptance of conflicting perspectives, a profound respect of others' lived differences, and a strategic awareness of cultural contexts that influence one's own beliefs, values, attitudes, and behaviors (Banks et al., 2005; Hoerder et al., 2006; MacPherson et al., 2004; Tellez \& Waxman, 2006).

\section{Methodology}

Guided by the theoretical frameworks described above, this study examines the knowledge construction of pre-service teachers, with respect to the learning of ESL students. I ask pre-service teachers to reflect critically on the incidents they are presented and then reflect on these incidents with respect to their own present and future practice.

Two research questions guided this study:

1. How do pre-service teachers interpret immigrant parent knowledge regarding ESL students' first language, culture and religion?

2. How do pre-service teachers respond to linguistic, cultural and religious diversity in their field experiences? 


\section{Dialogue across Differences}

I based the methods employed in this study on the notion of "diversity dialogue," proposed by Charles Taylor $(1994,1997)$. A diversity dialogue between parents and preservice teachers, or "dialogue across differences" as Burbules and Rice (1991) refer to it, can heighten our sensitivity to "how the 'same' thing might look and feel quite different to members of different cultural groups" (Burbules \& Rice, 1991, p. 405). Taylor (1994) suggests four steps for different parties to engage in "diversity dialogue." First, it is important to listen to other voices because each voice is unique. Second, it is significant to recognize and understand differences since non-recognition or misrecognition can inflict harm, and can be the basis of oppression and domination. Taylor challenges the ease with which we ascribe to "how we do things here," and holds out the possibility that we might recognize the worth of different cultures by expanding our horizons or fused horizons (Strike, 1996). The third step is to respect differences. The equal value of different cultures is not only recognized, but also cherished. The final step is to negotiate and accommodate differences. We can accommodate differences because cooperation allows us to build some remarkable things together (Taylor, 1997).

\section{Study Samples}

Two participant groups' experiences were brought together for this study. Parent participants - 38 in all - were recruited through the Coalition for Equal Access to Education in Calgary, Alberta. This is a local umbrella organization brings together community agencies, groups and individuals who are concerned with the current state of ESL instruction in the K-12 public education system and its consequences for immigrant children and families. The Coalition is committed to work with community, education and government stakeholders to promote access to quality, equitable education for culturally diverse children and youth.

The parents who participated in this study had recently arrived in Calgary. Their various countries of origin - 15 in total - included China, Korea, Vietnam, Nepal, the Philippines, India, Pakistan, Bangladesh, Algeria, Ghana, Somalia, Sudan, Columbia, Belize, and Suriname. Among parent participants, twenty-three different languages were spoken. All participants held credentials from their countries of origin. Twenty-five of the parents had bachelor degrees, twelve had master's degrees, and one had a high school diploma. Occupations held in countries of origin included university instructors, teachers, engineers, social workers, principals, and managers. Once in Canada, most experienced downward mobility; they became community liaison workers, cashiers, production workers, or were unemployed. Some parents gained knowledge of the Canadian school system by volunteering in schools, participating in school councils, or working in schools as lunch supervisors or teacher assistants. Some had directly observed teachers working with their children and were able to share these experiences. Semi-structured, individual interviews with parents were used to elicit their perspectives on what teachers ought know about their children. Each interview lasted from sixty to ninety minutes. 
The second participant group in this study consisted of 89 pre-service teachers enrolled in the University of Calgary's Master of Teaching (MT) programme, a two-year post-degree bachelor of education program. The pre-service teachers were representative of the nation's teaching force, which is predominantly white and female. The MT programme is inquiry-based learning, field-oriented, and learner-focused. The inquirybased stance means that students are asked to explore theories and issues through real-life cases, active questioning, and exposure to a wide range of materials. The program is unique because campus and field experiences are interwoven throughout the two years, providing students with ample opportunities to reflect on their field experiences.

In the first phase of the study, intercultural dialogues were held between the preservice teachers and parent leaders. This was followed by an online discussion. Finally focus groups were held with the participating teachers, in which they were asked to reflect on what they had learned from the exchanges with immigrant parents. Nine parent leaders were invited to share parent knowledge with four groups of pre-service teachers. Approximately twenty teachers participated in each group. Each of these dialogues lasted for approximately two hours. The discussion groups were held between March, 2009 and March, 2011. The sessions were audio-recorded, and the pre-service teachers' written reflections on these sessions were collected. In the second phase of the study, the pre-service teachers participated in an on-line forum, in which they were asked to reflect on how, during their field placements, they and their school communities responded to immigrant parents' knowledge. Online prompts included the following:

a) How are students' first languages valued in your schools? Can you give us an example?

b) Can you give us an example of cultural misunderstanding in your field experience? How is the misunderstanding resolved? What have you learned from this experience?

c) Some Muslim parents in our study requested a prayer space and to exempt their children from certain classes such as dancing and swimming, and sex education in public schools. How would you respond to these requests in your future teaching?

In the third and final segment of the study, focus groups were with the pre-service teachers to follow up on the questions that had been posed in the online forums. Each focus group was conducted at the end of a semester, following directly from the online forum that had preceded it over the term. The focus group works well in situations that involve investigating the attitudes and experiences of a homogeneous group of people regarding a specific issue (Krueger \& Casey, 2000). It allows for meanings to be shared and elaborated upon through group interaction. Focus groups provided a complementary methodology to expand upon the questions posed online. Five focus groups were conducted, and each group included between three and five students. Two students who were unable to attend the focus groups agreed to be interviewed individually. 


\section{Findings and Discussion}

Three major themes emerged from data analysis: students' first languages as a problem versus a resource; cultural misunderstanding and systemic racism; and tensions related to the accommodation of religion ain schools. In each case, we were able to identify how cultural variations in these knowledge areas contributed to misunderstandings between parents and teachers.

\section{Students' First Languages: Problem or Resource?}

The parent participants emphasized the importance of first language in their children's learning. Thirty-six out of thirty-eight parents in the study, however, reported that their children's schools often ignored their children's previous language knowledge. Parents thus informally taught their first languages to their children at home. The parents provided a number of reasons for passing on their linguistic values to their children. For some, teaching and preserving the first language at home was an important means of staying connected to relationships, cultural values, and identities forged in their home countries. Other parents listed more pragmatic reasons for keeping up the home language. They perceived that acquiring a new language would be useful for future employment in a global world. Others realized the first language is an important learning tool for transferring the concepts from first to second language education (Guo, in press).

Most pre-service teachers in our study were open to the use of ESL students' first languages at school. This new teacher, for example, viewed first language as a resource for ESL students' learning:

I think [students'] use of their mother tongue is helping them to succeed in the classroom, and catch on to concepts they might not understand.

Similarly, this teacher observed:

Students who speak the same languages assisted each other with math problems that one may not have understood but the other did. (pre-service teacher)

Some pre-service teachers noticed during their practicum that their schools encouraged the use of immigrant students' first language in their practicum; others observed that immigrant students' first languages were largely ignored:

I think it's like an afterthought for her [the partner teacher] that any of the children in her class actually speak a different language and it's kind of like a bonus when she remembers. The idea that students may speak other languages is not something that is thought about.

This pre-service teacher, however, felt overwhelmed by the need to become familiar with so many languages, and argued against their active inclusion in the classroom: 
I do not believe that teachers should allow for ESL students to use their first language at school. Teachers would have to be proficient in many languages due to the wide range of languages. This is because students could be talking about not appropriate things and no one would know...As well as, if ESL students were allowed to speak in their mother tongue other students may feel unwelcome around them.

Her reasoning - fear of her inability to monitor students for inappropriate behavior and the potential for other students to feel excluded -- is consistent with pre-service dominant attitudes found in studies conducted by De Courcy (2007) and Jones (2002).

Other pre-service teachers were simply uncertain of when and where it was appropriate to encourage the use of students' first language. One bilingual pre-service teacher shared that she felt uncomfortable speaking Korean to Korean students:

[The school] just got 3 brand new Korean girls and since I can speak it, I was speaking with them. Then when teachers would walk by I would feel kind of "What am I doing? Should I speak English? Why am I speaking Korean to them? Is this right?" I was second guessing myself and then I felt kind of uncomfortable talking in Korean with them. Like this isn't the way it should be, but still it's put on me that I need to be speaking English 'cause we're at an English school. (preservice teacher)

This pre-service teacher expressed an ideological dilemma (Billig et al., 1988): the monolingual ideology she had internalized through her own schooling experiences conflicted with the positive values she had acquired about multilingual education through her pre-service education.

\section{Cultural Misunderstanding and Systemic Racism}

In our interviews with immigrant parents, they emphasized how important it was that teachers understand the importance for teachers to understand their cultural beliefs and practices. A couple of cultural misunderstanding incidents from the interviews were shared with pre-service teachers. Two parents' accounts are particularly illustrative. A parent from South Korea recounted,

You know how she (the teacher) stated, "I think your son doesn't respect women...He doesn't look at me when I talk to him”...In our culture, it is a sign of respect. When the children talk to their parents and elders, they look down.

A parent from Pakistan described, similarly, how a teacher had misinterpreted a boy's behaviour:

Recently I was talking to one of the ESL teachers. She said she had one student from Pakistan and he is always following the teachers. She said, "I'm annoyed because he is just following me all the time." I said "It is not that he is following 
you. It shows respect. You know in our culture you can't walk in front of the teacher. So all he is doing is showing respect for you."

As they reflected on these incidents, pre-service teachers agreed that these incidents had occurred "due to teachers' lack of knowledge about students' culture." This pre-service teacher added,

It is so important to research behaviours, customs etc on the different cultures in your classroom, or things like this can happen. I had no idea about these types of customs, and I will definitely not forget it and hopefully recall them if I am faced in a similar type of situation.

Some pre-service teachers looked at these incidents more deeply, reflecting on the influence of their own socialization, and challenging teachers' tendencies to ethnocentrism. One teacher commented that "Canadian teachers were thinking of normal or abnormal based on what they know to be true and the norm in their own culture." Another stated,

I believe that the misunderstandings were caused through placing the norms of the culture in power on all students and assuming that they would understand and follow.

These participants questioned the tendency of those in the dominant culture to assume their own cultural values and practices are universal and "normal." Their critical insights allowed them to see the world through others' cultural and experiential lenses. children:

In another critical case, teachers heard this story about a Sudanese parent and her

One day, a 6-year-old child opened the fridge, got some food out, and played with the food. He went back to the fridge several times and got more food out and played with the food. His mother was tired of this and told the kid and his two siblings, "If you guys go again to the fridge, there is a lion there. Her purpose was not to let the kids touch the fridge... It came out in a classroom conversation. The 6-year old told his teacher he could not get food from the fridge because there was a lion there. So automatically, the teacher reported this incidence to social services. Social services took it serious and they took the kids away. A legal battle dragged the parents to the courts.

The pre-service teachers offered a variety of interpretations, for example that the teacher may have thought the child wasn't being fed. Most realized that the African mother was trying to scare her child into behaving, just as a North American parent might say "if you misbehave, the bogeyman downstairs will get you."

Some participants felt the teacher's reaction was racist. One pre-service teacher commented: 
I'm sure that I could get away with far worse and even genuinely destructive behaviour with my own daughter and not suffer the same consequence, as I am an established member of the dominant culture. It seems by the stories that the Sudanese families are being singled out- that their culture is being seen as far more suspect than any particular actions being taken by individual families.

The teacher was aware of his own white privilege, and questioned whether systemic racism towards Sudanese parents may have played a role in the teacher's misconceptions.

\section{Tensions about Religious Accommodations}

Thirteen out of the thirty-eight immigrant parents in the study were Muslim, hailing from Pakistan, Bangladesh, India, Algeria, and Somali. They stated that one of the reasons for them to immigrate to Canada had been their attraction of its official policies of multiculturalism. Understanding, as one of these parents observed, that religious freedom is enshrined in Canada's Charter of Rights and Freedoms, the parents had expected the accommodation of religious practices in schools, including the allowing Muslim girls to wear a headscarf. However, practice of hijab remains poorly understood in Canada. This parent, for example, described how some teachers initially reacted toward her:

I wear a headscarf when I go to parent-teacher conferences. The majority of the people, I have noticed their initial impression about me would be I am a dumb person because I wear that.

In fact, this Muslim mother had received all her education in English and obtained a Master of Science degree in India before she immigrated to Canada. She spoke fluent English, volunteered in school activities, and participated in the school council. "They [the teachers] thought I am oppressed," she continued. "I am not oppressed at home." As a single mother, she was raising two children by herself, and encouraged her daughter to pursue a law career.

The pre-service teachers reflected on the commonly held belief that hijab is "a symbol of women's marginalization" (Subedi, 2006, p. 234). One pre-service teacher wrote: "I think the teachers... perhaps assumed that the headscarf was a means to control women and women wore it against their will." The pre-service teacher realized because of their limited knowledge of different religions, many teachers could fall back on stereotypes and unexamined beliefs. As one new teacher observed,

When we see someone dress differently, look differently, we associate that with the fact that they must not know English. If that person can't communicate at the same level, then they must be dumb....this superior/inferior attitude remains. It takes a teacher to acknowledge their own inhibitions and move past this general negative attitude towards others. 
She argued that it is important for educators to guard against equating difference in dress English language ability to a lack of intelligence, or a cultural or educational backwardness (Zine, 2006). Such assumptions are based on stereotypes "reminiscent of the long-gone colonial era" (Rezai-Rashti, 1994, p. 37).

In addition to requesting Muslim girls to wear a headscarf, twelve out of the thirteen Muslim parents believed that Muslim girls should be segregated from the opposite sex, so girls are not allowed to wear swimming suits or dance with boys. Aneeka, mother of a 15-year-old daughter said:

In our religion we believe in gender segregation. The man is not supposed to see the beauty of women. I did go and talk to the teacher at the beginning of the school year that my daughter does not swim and dance with boys (Aneeka, Pakistan).

Aneeka requested her children to exempt from swimming and dancing classes. Sana, mother of a 12-year-old daughter expressed her disappointment that some teachers were not sensitive to her religious needs and did not allow exemptions:

I went to the school and told her teacher we don't allow her to participate in the swimming classes. The teacher was annoyed. She didn't understand and made a big deal: 'This is physical education class. She has to be part of it.'

Donika went beyond exemptions by suggesting that schools need to rethink the requirement for swim wear:

This kid was crying because she was not allowed to wear the swimming suit. The teacher in fact forced her to wear the swimming suit. The only thing that this teacher had in her mind is that you can only swim in the swimming suit. That's not true, a real mistake (Donika, Suriname).

Donika stressed the importance for educators to be open to different perspectives and realize that there are many different ways of doing the same thing. She suggested that schools should allow Muslim girls to wear full body suits instead of swim suits.

The pre-service teachers responded to the parents' request of exemptions from swimming and dancing classed in different ways. For example, one pre-service teacher responded:

Should the religious and cultural beliefs of one person change the learning experience of all the children in the class? I honestly have no idea what I would do if a parent requested I change the core of my teaching practice.

This pre-serve teacher was not sensitive to the religious needs of her students and did not allow exemptions. She failed to recognize that religion is an essential part of education for some students and failed to accommodate religious difference. Another pre-service 
teacher realized the importance to respect the parent's religious beliefs, but was worried about her Muslim students:

In many cultures, males and females are segregated and this has to do with comfort level. However, in western society it is not the case...It is important to accept religious beliefs but it is also important to be able to function in the society they live in. (pre-service teacher)

This pre-serve teacher said in Canada we are not segregated and these students will be expected to work with the opposite sex in many situations in the future. She was torn between religious accommodations and supporting Muslim students to function in the Canadian society. Religious continuity within Canadian schools is important for some Muslim parents. For teachers, dancing and swimming are part of school curricula and students are required to participate in these classes for their physical and social development. Where the rule in swimming class is that everyone must wear swimming suits or in gym class shorts and T-shirts, religious students should be exempt from the class, or be put in an alternative class (Levy, 1997; Spinner-Halev, 2000). The clothing requirement should also be rethought and students should be allowed to wear full body suits.

\section{Implications for Theory and Practice}

Results of the study provide both theoretical and practical implications. Theoretically, the study calls for the reconstruction of difference and the inclusion of epistemological pluralism, particularly immigrant parent knowledge, within teacher education (Abdi, 2009; Andreotti, Ahenakew \& Cooper, 2011; Kelly, Shultz, WeberPillwax \& Lange, 2009). Practically, the study suggests that it is important to help preservice teachers shift their representation of multilingualism from being a problem to a resource, challenge their Eurocentric beliefs, understand immigrant students' cultural backgrounds, and address religious-based exemptions and accommodations.

Teacher education in today's immigration context must be reconceptualized to address what it means to teach in multilingual, multicultural, and multireligious schools. Further to the development of interlinguistic and intercultural competence I argued elsewhere (Guo, Arthur \& Lund, 2009; Hébert, Guo \& Pellerin, 2008), it is necessary to implement antiracism education in teacher education so as to overcome an underlying but pervasive fear of difference. The label of difference should be reconstructed. There is a need to move from viewing difference as deficit to understanding and appreciating difference as the most fundamental trait of humanity, as positive, and enriching our lives (Abdi, Shultz, \& Purton, 2012). From this perspective, educators need to see immigrant children and parents as capable to their own well-being. From this perspective, it is important to understand the significant knowledge possessed by many parents in the study, including their understanding of ESL learners' linguistic, cultural, and religious backgrounds, life experiences of living with many cultures, and community issues. Teachers need to create a space intentionally to invite and affirm immigrant parent knowledge and their knowledge to be acted on in decisions about their children's 
teaching and learning (Pushor \& Murphy, 2004). The study indicates the importance for recognition, legitimatization, and representation of immigrant parent knowledge in teacher education (Fraser, 2009).

\section{Multilingualism}

The parents in the study recognized that students' first language is an important component of their identity, a useful tool for thinking and learning, and a valuable medium for effective communication in the family and the community. Their argument for the importance of first language challenged the assumption that English language teaching should be conducted monolingually through English. Pre-service teachers responded to such argument differently. Some pre-service teachers viewed their students' first language as a resource; others viewed it as a problem, while some internalized monolingual ideology despite multilingual realities. Some pre-service teachers developed a fear of the use of students' first language: "teachers would have to be proficient in many languages due to the wide range of languages", said one pre-service teacher. To this pre-service teacher, the presence of multiple languages in the classroom threatens her position of authority. Consequently, she argues for her monolingual practice in the classroom because of her inability to monitor students for inappropriate behaviour in different languages. Similar findings have been reported in previous educational research (De Courcy, 2007; Skilton-Sylvester, 2003).

The study indicates that it is important for teacher educators to help pre-service teachers to shift their representations of multilingualism from being a problem to being a resource. An example would be the use of dual-language books, where the text is in both English and another language. A kindergarten teacher, a graduate student in my course, invited parents from 11 different languages to be part of a family reading program in her classroom. Every Friday, she allocated 25 minutes at the drop-off time for parent volunteers to read to small groups of children, often from dual-language books, on their own or with a partner parent reading the English text (Sarah Harrison, personal communication, December 16, 2010). The teacher reported the increasing appreciation of the children toward their classmates' multilingual abilities, as well as how much the parents of these children valued the opportunity to share their first languages and be part of the learning community. This example supports that legitimating students' first language as a cognitive tool within the classroom challenges the colonial ideology - the superiority of speaking only English to speaking multiple languages ( $\mathrm{Yu}, 2010)$. It also challenges the subordinate status of many minority groups and affirms students' identities of competence (Cummins, 2009).

\section{Understanding Cultural Difference and Overcoming Systemic Racism}

The parents emphasized the importance for teachers to understand their cultural beliefs and practices, such as not looking at the teacher when speaking and walking behind the teacher were signs of showing respect in immigrant cultures. In the incident of "there is a lion in the refrigerator," the parent tried to prevent the child from continuing with behaviour unacceptable to her although attractive to the child. The teacher took the 
story literally and assumed the child was not being fed or in fear. She assumed the parent prevented the child from eating and thus the parent must be abusive and neglectful. The teacher's assumption was based upon permissive culture of children in North America where they were allowed to eat anytime (Barton, 2009). This example demonstrated misunderstanding of what counts child-rearing and discipline, values deeply embedded in cultures.

Most pre-service teachers recognized cultural misunderstandings between immigrant parents and Canadian teachers. Some questioned the tendency of those in the dominant culture to assume their own cultural values and practices are universal and "normal." They recognized that for the African parent, saying "there is a lion in the refrigerator" is a scare tact used by parents in many cultures, including their own parents, to discipline children. By using what they would call "if you misbehave, the bogeyman downstairs will get you", the parent reconditioned the child to the fridge by replacing the 'attractant' in the child's mind with an aversion-fear of anxiety would now be provoked and the result achieved by the parent. One pre-service teacher was aware that as a white parent, he did not need to "suffer the same consequence." He questioned whether systemic racism towards Sudanese parents may have contributed to the teacher's misassumptions. The example illustrated it is important for teachers to "challenge Eurocentric beliefs and practices and move from a position that assumes a singular, monocultural reality, to adopting a worldview that is respectful of multiple belief systems" (Guo, Arthur \& Lund, 2009, p. 574).

This study suggests that pre-service teachers need to unlearn their privilege and need to recognize and make use of the knowledge of immigrant parents to provide a better public education for immigrant students. It is also important for teacher educators to support pre-service teachers in developing a critical awareness of cultural and religious discrimination and the attitudes underlying it.

\section{Religious Diversity}

In response to the recognition of the religious diversity, public schools are required to inform administrators and teachers about the religious practices of their students. Religious discrimination derives in part from religious illiteracy. As White (2009, p. 859) noted, "religion exists in multiculturalism, but it is often omitted from multicultural education.' Religious illiteracy has meant that teachers (the majority of who are at least nominally Christian) often fail to discuss or even understand the religions dimensions of policy challenges (Sumyu Neufeld, personal communication, January 6, 2010). This illiteracy can be addressed with mandatory education on world religions as subjects for respectful study but not indoctrination for all pre-service teachers (Bouchard \& Taylor, 2008; Bramadat \& Selijak, 2005). Religion is an important part of a wellrounded academic education. Learning about it will help teachers and students overcome their fear and support social interaction between immigrant and non-immigrant students (Spinner-Halev, 2000). 
It is important for educators to provide institutionalized means for the explicit recognition and representation of oppressed groups. Part of these means include modifications of school curricula, dress codes, provision of prayer rooms for Muslim students (Kanu, 2008), and also state funding for privately established Muslims schools in the same way that Catholic schools are funded ${ }^{\mathrm{i}}$, which are necessary to reflect contemporary and religiously pluralistic realities.

\section{References}

Abdi, A. (2007). Global multiculturalism: Africa and the recasting of the philosophical and epistemological plateaus. Diaspora, Indigenous and Minority Education, 1 (4), 1-14.

Abdi, A. (2009). Recentering the philosophical foundations of knowledge: The case of Africa with a special focus on the global role of teachers. Alberta Journal of Educational Research, 55(3), 269-283.

Abdi, A., Schultz, L., \& Purton, F. (February 23, 2012). Do we know our new students? Social justice, global citizenship and the dignity of difference. Workshop conducted at the Conference of the Western Canadian Association for Student Teaching (WestCAST), Calgary, Alberta, Canada.

Alberta Education. (2011). Response to email inquiry about number of ESL students in Alberta. Edmonton: Alberta Education.

Andreotti, V., Ahenakew, C., \& Cooper, G. (2011). Epistemological pluralism: Ethical and pedagogical challenges in higher education. AlterNative: An International Journal of Indigenous Peoples, 7(1), 40-50.

Appadurai, A. (1996). Modernity at large: Cultural dimensions of modernity. London and Minneapolis: University of Minnesota Press.

Banks, J., Cochran-Smith, M., Moll, L., Richert, A., Zeichner, K., LePage, P., DarlingHammond, L., Duffy, H., \& McDonald, M. (2005). Teaching diverse learners. In L. Darling-Hammond \& J. Bransford (Eds.), Preparing teachers for a changing world: What teachers should learn and be able to do (pp. 232-274). San Francisco: Jossey-Bass.

Barton, A. (November 30, 2009). Are you raising a bratty kid? Globe and Mail. Retrieved September 23, 2011, from http://www.theglobeandmail.com/life/family-and-relationships/are-you-raising-abratty-kid/article1382205/

Bernhard, J.K., Freire, M., Pacini-Ketchabaw, V., \& Villanueva, V. (1998). A LatinAmerican parents' group participates in their children schooling: Parent involvement reconsidered. Canadian Ethnic Studies, 30(3), 77-99.

Billig, M., Condor, S., Edwards, D., Gane, M., Middleton, D., \& Radley, A. (1988). Ideological dilemmas: A social psychology of everyday thinking. Newbury Park, CA: Sage.

Bitew, C., \& Ferguson, P. (2010). Parental support for African immigrant students' schooling in Australia. Journal of Comparative Family Studies, 41(1), 149-165.

Bouchard, G., \& Taylor, C. (2008). Building the future: A time for reconciliation. Retrieved November 23, 2011, from 
http://www.accommodements.qc.ca/documentation/rapports/rapport-finalabrege-en.pdf

Bramadat, P., \& Seljak, D. (2005). (Eds.). Religion and ethnicity in Canada. Toronto: Pearson.

Burbules, N., \& Rice, S. (1991). Dialogue across differences: Continuing the conversation. Harvard Educational Review, 61 (4), 393-416.

Calderhead, J., \& Gates, P. (Eds.). (1993). Conceptualizing reflection in teacher development. London: Falmer Press.

Connelly, F.M., \& Clandinin, D.J. (1988). Teachers as curriculum planners: Narratives of experience. New York, NY: Teachers College Press.

Cosh, J. (1998). Peer consultation in higher education - a reflective approach. Innovations in Education and Training International, 35(2), 171-176.

Creswell, J. (1997). Qualitative inquiry and research design choosing among five traditions, Thousand Oaks, CA: Sage Publications.

Cummins, J. (2003). Challenging the construction of difference as deficit: Where are identity, intellect, imagination, and power in the new regime of truth? In P. P. Trifonas (Ed.), Pedagogy of difference: Rethinking education for social change (pp. 41-60). New York: RoutledgeFalmer.

Cummins, J. (2009). Multilingualism in the English-language classroom: Pedagogical considerations. TESOL Quarterly, 43(2), 317-321.

De Courcy, M. (2007). Disrupting preconceptions: Challenges to pre-service teachers' beliefs about ESL children. Journal of Multilingual and Multicultural Development, 28(3), 188-203.

Dei, G. (1996). Anti-racism education: Theory and practice. Halifax: Fernwood Publishing.

De Sousa Santos, B. (Ed.). (2007). Cognitive justice in a global world: Prudent knowledge for a decent life. Lanham, MD: Lexington.

Dewey, J. (1933). How we think. Chicago: Henry Regnery. (Original work published 1910)

Dunn, W., Kirova, A., Cooley, M., \& Ogilvie, G. (2009). Fostering intercultural inquiry in subject-area curriculum courses. Canadian Journal of Education, 32(3), 533557.

Fraser, N. (2009). Scales of justice: Reimagining political space in a globalizing world. New York: Columbia University Press.

Guo, S. (2009). Difference, deficiency, and devaluation: Tracing the roots of non/recognition of foreign credentials for immigrant professionals in Canada. Canadian Journal for the Study of Adult Education, 22(1), 37-52.

Guo, Y. (2005). An investigation of ESL teachers' experience of peer consultation. Canadian Journal of University Continuing Education, 31(2), 17-36.

Guo, Y. (2006). "Why didn't they show up?": Rethinking ESL parent involvement in K12 education. TESL Canada Journal, 24 (1), 80-95.

Guo, Y. (in press). Diversity in public education: Acknowledging immigrant parent knowledge. Canadian Journal of Education.

Guo, Y., Arthur, N., \& Lund, D. (2009). Intercultural inquiry with pre-service teachers. Intercultural Education, 20(6), 565-577. 
Hannerz, U. (1992). Flows, boundaries and hybrids: Keywords in transcultural anthropology. In A. Rogers, Ed., Working Paper Series, WPTC-2K-02, Transnational Communities Programme, Oxford U. Retrieved on June 5, 2011, from www.transcomm.ox.ac.uk/working\%20papers/hannerz.pdf

Hébert, Y., Guo, Y., \& Pellerin, M. (2008). New horizons for research on bilingualism and plurilingualism: A focus on languages of immigration in Canada. Encounters on Education, 9, 57-74.

Hodgkinson, H. (2002). Demographics and teacher education: An overview. Journal of Teacher education, 53(2): 102-105.

Hoerder, D., Hébert, Y., \& Schmitt, I. (Eds.). (2006). Negotiating transcultural lives: Belongings and social capital among youth in comparative perspectives. Toronto: University of Toronto Press.

Honneth, A. (1995). The struggle for recognition: The moral grammar of social conflicts. Boston: MIT Press.

Jones, T.G. (February 23-26, 2002). Preparing all teachers for linguistic diversity in $K$ 12 schools. Paper presented at the Annual Meeting of the American Association of Colleges for Teacher Education, New York.

Jones, T.G. (2003). Contributions of Hispanic parents' perspectives to teacher preparation. The School Community Journal, 13(2), 73-96.

Kanu, Y. (2008). Educational needs and barriers for African refugee students in Manitoba. Canadian Journal of Education, 31(4), 915-940.

Kelly, J., Shultz, L., Weber-Pillwax, C., \& Lange, E. (2009). Expanding knowledge systems in teacher education: Introduction. Alberta Journal of Educational Research, 55(3), 263-268.

Krueger, R., \& Casey, M. (2000). Focus groups: A practical guide for applied research (3rd ed.). Thousand Oaks, CA: Sage Publications.

Lareau, A. (2003). Unequal childhoods: Class, race, and family life. Berkeley: University of California Press.

Levy, J.T. (1997). Classifying cultural rights. In I. Shapiro \& W. Kymlicka (Eds.), Ethnicity and group rights (pp. 22-66). New York, NY: New York University Press.

MacPherson, S., Turner, D., Khan, R., Hingley, W., Tigchelarr, A., \& Lafond, L.D. (2004). ESL and Canadian multiculturalism: Multilingual, intercultural practices for the 21st century. TESL Canada Journal, 4, 1-22.

Malatest, R.A., \& Associates Ltd. (2003). Efficacy of Alberta teacher preparation programs and beginning teachers' professional development opportunities. 2002 survey report. Unpublished manuscript. Edmonton, AB: Alberta Learning.

McDonough, S., \& Hoodfar, H. (2005). Muslims in Canada: From ethnic groups to religious community. In P. Bramadat \& D. Seljak (Eds.), Religion and ethnicity in Canada (pp. 133-153). Pearson Education Canada Inc, Toronto.

McLaren, P. (2003). Life in schools: An introduction to critical pedagogy in the foundations of education. Boston: Pearson Education.

Meyer, M. (2003). Myths and delusions: The state of ESL in large Canadian school boards. Toronto: Mainstream Publications. Retrieved June 8, 2011, from www.teslontario.org/new/research/MythsandDelusions.pdf 
Miles, M.B., \& Hubermam, A.M. (1994). Qualitative data analysis: An expanded source book (2nd ed.).Thousand Oaks, CA: Sage Publications. Mujawamariya, D., \& Mahrouse, G. (2004). Multicultural education in Canadian preservice programs: Teacher candidates' perspective. Alberta Journal of Educational Research, 50, 336-353.

Milner, H. R. (2003). Reflection, racial competence, and critical pedagogy: How do we prepare pre-service teachers to pose tough questions? Race, Ethnicity and Education, 62(2), 193-208.

Palmer, P. (1998). The courage to teach: Exploring the inner landscape of a teacher's life. San Francisco: Jossey-Bass.

Polanyi, M. (1958). Personal knowledge: Towards a post-critical philosophy. Chicago: University of Chicago Press.

Pushor, D. (2008, March). Parent knowledge: Acknowledging parents. Paper presented at the Annual Meeting of the American Educational Research Association, New York.

Pushor, D. \& Murphy, B. (2004). Parent marginalization, marginalized parents: Creating a place for parents on the school landscape. Alberta Journal of Educational Research, 50(3), 221-235.

Ramirez, A.Y. (2003). Dismay and disappointment: Parental involvement of Latino immigrant parents. The Urban Review, 35, 93-110.

Rezai-Rashti, G. (1994). Islamic identity and racism. Orbit, 25(2), 37-38.

Schön, D.A. (1983). The reflective practitioner: How professionals think in action. New York: Basic Books.

Shultz, L. (2011). Engaging the multiple discourses of global citizenship education within a Canadian university: Deliberation, contestation, and social justice possibilities. In L. Shultz, A. A., Abdi \& G. Richardson (Eds.), Global citizenship education in post-secondary institutions: Theories, practices, policies (pp. 13-24). New York: Peter Lang.

Skilton-Sylvester, E. (2003). Legal discourse and decisions, teacher policymaking and the multilingual classroom: Constraining and supporting Khmer/English biliteracy in the United States. In A. Creese \& P. Martin (Eds.), Multilingual classroom ecologies: Inter-relationships, interactions and ideologies (pp. 8-24). Clevedon: Multilingual Matters.

Spinner-Halev, J. (2000). Surviving diversity: Religious and democratic citizenship. The John Hopkins University Press, Baltimore, MD.

Statistics Canada. (2005). Population projections of visible minority groups, Canada, provinces and regions 2001-2017. Ottawa: Statistics Canada.

Statistics Canada. (2007, December 4). 2006 Census: Immigration, citizenship, language, mobility and migration. The Daily. Retrieved September 11, 2011, from http://www.statcan.gc.ca/daily-quotidien/071204/dq071204a-eng.htm

Statistics Canada. (2008). The evolving linguistic portrait, 2006 Census. Ottawa: Statistics Canada. Retrieved October 22, 2011, from http://www12.statcan.ca/english/census06/analysis/language/pdf/97-555XIE2006001.pdf

Strike, K. (1996). Taylor, equality, and the metaphysics of persons. Retrieved October 22, 2011, from http://www.ed.uiun.edu/EPS/PES_Yearbook?96_docs/strike.html 
Subedi, B. (2006). Preservice teachers' beliefs and practices: Religion and religious diversity. Equity and Excellence in Education, 39(3), 227-238.

Taylor, C. (1994). The politics of recognition. In A. Gutmann (Ed.), Multiculturalism: Examining the politics of recognition (pp. 25-73). Princeton University Press, Princeton, NJ.

Taylor, C. (1997, September 21). Negotiating the differences. Interview conducted by CBC Radio. Toronto, Ontario, Canada.

Taylor, S. B., \& Sobel, D. M. (2001). Addressing the discontinuity of students' and teachers' diversity: A preliminary study of preservice teachers' beliefs and perceived skills. Teaching and Teacher Education, 17(4), 487-503.

Tellez, K., Waxman, H.C. (Eds.). (2006). Preparing quality educators for English language learners: Research, policies, and practices. Mahwah, NJ: Lawrence Erlbaum Associates.

Turner, J. D (2007). Beyond cultural awareness: Prospective teachers' visions of culturally responsive literacy teaching. Action in Teacher Education, 29(3), 12-24.

White, K.R. (2009). Connecting religion and teacher identity: The unexplored relationship between teachers and religion in public schools. Teaching and Teacher Education, 25, 857-866.

Yu, H. (February 1, 2010). Vancouver's own not-so-quiet revolution. Vancouver Sun.

Zine, J. (2006). Unveiled sentiments: Gendered Islamophobia and experiences of veiling among Muslim girls in a Canadian Islamic school. Equity \& Excellence in Education, 39, 239-252.

\footnotetext{
${ }^{\mathrm{i}}$ Roman Catholic schools in Ontario, Saskatchewan, Alberta and the Northwest Territories along with other religiously based schools receive public funding in many provinces.
} 